\title{
A case of septic pulmonary embolism caused by $P$. aeruginosa in a hemodialysis patient and review of the literature
}

\author{
Hiroki Shimada*, Mari Tanaka, Yohtaro Takami, Mariko Teragaki, Kotaro Maeda, Hirona Saita, Seira Nishikawa,
} Keisuke Taniguchi, Sachio Iwanari, Masaki Ikeda and Hiroya Takeoka

\begin{abstract}
Background: Septic pulmonary embolism (SPE) is an uncommon but serious complication resulting from infection of the blood. Gram-positive cocci, including methicillin-susceptible Staphylococcus aureus and methicillin-resistant Staphylococcus aureus, are the most common causative organisms of SPE. Few case reports have been published on SPE caused by Pseudomonas aeruginosa (P. aeruginosa), and thus, the consensus treatment of SPE caused by $P$. aeruginosa infections remains undetermined. Management of $P$. aeruginosa infection can be challenging due to its poor prognosis and antimicrobial resistance. Here, we report a case of successful combination antibiotic therapy for SPE associated with infective endocarditis (IE) caused by $P$. aeruginosa in a hemodialysis patient, with a review of the literature.

Case presentation: A 62-year-old man receiving maintenance hemodialysis as treatment for end-stage renal disease due to IgA nephropathy was admitted to our hospital with high fever and chills lasting 10 days. Chest computed tomography revealed multiple nodular shadows, and gram-negative rods were confirmed by blood culture obtained on admission. We suspected SPE and initiated meropenem (MEPM) treatment. P. aeruginosa was identified in blood cultures, and transesophageal echocardiography demonstrated vegetation on the tricuspid valve. Therefore, a diagnosis of SPE associated with IE caused by P. aeruginosa was made. P. aeruginosa isolates showed good susceptibility to MEPM, but no symptomatic improvement was observed. Thus, antibiotics were changed from MEPM to a combination of ceftazidime and tobramycin (TOB). The patient exhibited a favorable response to the combination therapy, although we discontinued TOB on day 23 because of tinnitus symptoms.
\end{abstract}

Conclusions: We report a rare case of SPE associated with IE caused by P. aeruginosa in a hemodialysis patient. Combination antibiotic therapy may be effective in this situation.

Keywords: Hemodialysis, Septic pulmonary embolism, Pseudomonas aeruginosa, Infective endocarditis, Combination antibiotic therapy

\footnotetext{
*Correspondence: greatdavidson6609@gmail.com

Department of Nephrology and Dialysis, Hyogo Prefectural Amagasaki General Medical Center, 2-17-77 Higashinaniwa-cho, Amagasaki, Hyogo 660-8550, Japan
}

(c) The Author(s). 2020 Open Access This article is licensed under a Creative Commons Attribution 4.0 International License, which permits use, sharing, adaptation, distribution and reproduction in any medium or format, as long as you give appropriate credit to the original author(s) and the source, provide a link to the Creative Commons licence, and indicate if changes were made. The images or other third party material in this article are included in the article's Creative Commons licence, unless indicated otherwise in a credit line to the material. If material is not included in the article's Creative Commons licence and your intended use is not permitted by statutory regulation or exceeds the permitted use, you will need to obtain permission directly from the copyright holder. To view a copy of this licence, visit http://creativecommons.org/licenses/by/4.0/ The Creative Commons Public Domain Dedication waiver (http://creativecommons.org/publicdomain/zero/1.0/) applies to the data made available in this article, unless otherwise stated in a credit line to the data. 


\section{Background}

Septic pulmonary embolism (SPE) is an uncommon complication in which infected thrombi from a primary infectious site lead to infarctions in the pulmonary vasculature [1]. Very few case reports have been published on SPE caused by Pseudomonas aeruginosa ( $P$. aeruginosa); therefore, no consensus has been reached as to the treatment of SPE caused by $P$. aeruginosa. We report our rare experience with successful combination antibiotic therapy for SPE associated with infective endocarditis (IE) caused by $P$. aeruginosa in a hemodialysis patient.

\section{Case presentation}

A 62-year-old man was admitted to our hospital with a 10-day history of high fever and chills. He developed end-stage renal disease due to IgA nephropathy 16 years ago and started maintenance hemodialysis through a native arteriovenous fistula. He did not take any antibiotics prior to admission. On admission, his body temperature was $37.5^{\circ} \mathrm{C}$, his blood pressure was $108 / 69 \mathrm{mmHg}$, his respiratory rate was 12 breaths/min, his $\mathrm{SpO}_{2}$ was $96 \%$ in ambient air, and he presented with tachycardia (120 beats/min). On physical examination, no obvious evidence of an infection site was observed, including the infection of arteriovenous fistula. He experienced no respiratory symptoms, and his breath and heart sounds were normal. Complete blood counts showed a white blood cell count of $25,800 / \mu \mathrm{L}$ with a left shift, hemoglobin of $11.8 \mathrm{~g} / \mathrm{dL}$, and a platelet count of 163 , $000 / \mu \mathrm{L}$. The results of blood chemistry tests were as follows: aspartate aminotransferase $31 \mathrm{IU} / \mathrm{L}$, alanine aminotransferase $32 \mathrm{IU} / \mathrm{L}$, total protein $6.3 \mathrm{~g} / \mathrm{dL}$, albumin $3.6 \mathrm{~g} /$ $\mathrm{dL}$, blood urea nitrogen $32.9 \mathrm{mg} / \mathrm{dL}$, and creatinine 9.08 $\mathrm{mg} / \mathrm{dL}$. Lactate dehydrogenase was $227 \mathrm{IU} / \mathrm{L}$, and C- reactive protein was $23.27 \mathrm{mg} / \mathrm{dL}$. Laboratory results are summarized in Table 1 . Chest X-ray and contrastenhanced chest computed tomography (CT) revealed multiple bilateral peripheral nodular lesions in both lungs (Fig. 1a). Meropenem (MEPM) (1 g daily) was administered as the initial antibiotic treatment. Later, $P$. aeruginosa was detected in 2 of 4 blood cultures. Clinical symptoms, positive blood culture results, and imaging findings of pulmonary thrombosis suggested the presence of SPE. Transthoracic echocardiography revealed no vegetation, but transesophageal echocardiography demonstrated a mobile vegetation of $8 \mathrm{~mm}$ on the tricuspid valve. No obvious findings of congenital heart disease or valvular disease were observed. The diagnosis of SPE associated with IE caused by $P$. aeruginosa was made based on these findings. Although the isolated bacterium exhibited good susceptibility to MEPM, the patient's fever was prolonged and CT findings worsened compared with those on admission (Figs. 1b, 2). Then, we changed MEPM to a combination therapy of ceftazidime (2 g daily) and tobramycin (TOB) (120 mg after each hemodialysis session). After changing antibiotics, his fever and leukocytosis resolved. He experienced tinnitus on day 23 and thus TOB was stopped due to suspicion of adverse effects. After TOB was stopped, his tinnitus resolved and he completed 6 weeks of antibiotic therapy. On day 51, he was discharged from our hospital without any symptoms.

\section{Discussion and conclusions}

SPE is an uncommon but serious disease characterized by pulmonary embolism of infected thrombi from a primary infectious site. The diagnostic criteria of SPE have not been established, and diagnosis is generally made

Table 1 Baseline laboratory results of the patient

\begin{tabular}{|c|c|c|c|c|c|}
\hline WBC count & $25,800 / \mu \mathrm{L}$ & AST & $31 \mathrm{U} / \mathrm{L}$ & $\mathrm{Cl}$ & $100 \mathrm{mEq} / \mathrm{L}$ \\
\hline Neutrophils & $88 \%$ & ALT & $32 \mathrm{U} / \mathrm{L}$ & $\mathrm{Ca}$ & $10.3 \mathrm{mg} / \mathrm{dL}$ \\
\hline Eosinophils & $0 \%$ & $\mathrm{LDH}$ & $227 \mathrm{U} / \mathrm{L}$ & $P$ & $5.1 \mathrm{mg} / \mathrm{dL}$ \\
\hline Basophils & $1 \%$ & ALP & $270 \mathrm{U} / \mathrm{L}$ & CRP & $23.27 \mathrm{mg} / \mathrm{dL}$ \\
\hline Lymphocytes & $3 \%$ & Cholinesterase & 199 U/L & $\mathrm{Fe}$ & $5 \mu \mathrm{g} / \mathrm{dL}$ \\
\hline Monocytes & $8 \%$ & Total bilirubin & $0.5 \mathrm{mg} / \mathrm{dL}$ & UIBC & $195 \mu \mathrm{g} / \mathrm{dL}$ \\
\hline RBC count & $364 \times 10^{4} / \mu \mathrm{L}$ & Total protein & $6.3 \mathrm{~g} / \mathrm{dL}$ & Ferritin & $135.0 \mathrm{ng} / \mathrm{mL}$ \\
\hline Hemoglobin & $11.8 \mathrm{~g} / \mathrm{dL}$ & Albumin & $3.6 \mathrm{~g} / \mathrm{dL}$ & BNP & $428.7 \mathrm{pg} / \mathrm{mL}$ \\
\hline Hematocrit & $35.9 \%$ & BUN & $32.9 \mathrm{mg} / \mathrm{dL}$ & & \\
\hline Platelet count & $163,000 / \mu \mathrm{L}$ & Creatinine & $9.08 \mathrm{mg} / \mathrm{dL}$ & & \\
\hline PT & $80.9 \%$ & eGFR & $5 \mathrm{~mL} / \mathrm{min} / 1.73 \mathrm{~m}^{2}$ & & \\
\hline APTT & $28.3 \mathrm{~s}$ & $\mathrm{Na}$ & 140 mEq/L & & \\
\hline Fibrinogen & $533.0 \mathrm{mg} / \mathrm{dL}$ & K & $4.9 \mathrm{mEq} / \mathrm{L}$ & & \\
\hline
\end{tabular}

WBC white blood cell, RBC red blood cell, $P T$ prothrombin time, $A P T T$ activated partial thromboplastin time, $A S T$ aspartate transaminase, $A L T$ alanine aminotransferase, $L D H$ lactate dehydrogenase, $A L P$ alkaline phosphatase, $B U N$ blood urea nitrogen, eGFR estimated glomerular filtration rate, $C R P C$-reactive protein, UIBC unsaturated iron binding capacity, $B N P$ brain natriuretic peptide 

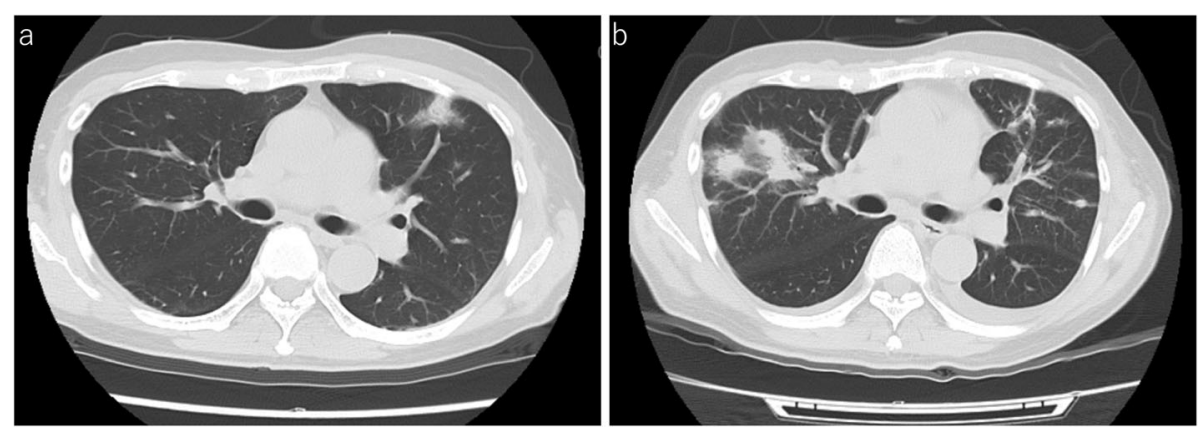

Fig. 1 a Chest CT scan on admission shows multiple nodular lesions in both lungs. b Repeated chest CT scan 9 days later shows worsening lung nodular lesions

based on the presence of predisposing infectious sites, febrile illness, and lung CT findings [2]. Typical CT findings include multiple peripheral lung nodules with or without cavitations, pleura-abutting wedge-shaped peripheral lesions, a feeding vessel sign, and pleural effusion [3]. In our case, we made the diagnosis of SPE based on fever, blood culture results, multiple peripheral nodules visible on chest $\mathrm{CT}$, and the presence of right-sided IE as the predisposing infectious site. The primary infectious sites of SPE include right-sided IE, pelvic thrombophlebitis, head and neck infections, vascular catheters, implantable devices, and soft tissue infections $[2,4]$. The risk factors for SPE include intravenous drug use, catheter insertion, and diabetes mellitus [5]. In addition, in the single-center retrospective analysis of 40 SPE patients, up to $25 \%$ of patients (10 patients) were hemodialysis patients [4]; thus, hemodialysis may be a risk factor for SPE. We should therefore consider SPE when we examine hemodialysis patients with fever and bacteremia.
The most common causative organisms of SPE are methicillin-susceptible Staphylococcus aureus (32\%), methicillin-resistant Staphylococcus aureus (18\%), Fusobacteria (7\%), Klebsiella (7\%), Candida (4\%), and Streptococcus viridans (3\%) [6]. SPE caused by P. aeruginosa, which is the pathogenic organism in our case, has only been rarely reported. To the best of our knowledge, only eight reports of SPE caused by $P$. aeruginosa exist in the literature. Table 2 lists the clinical features of six reports including our case, except for two reports that provided no detailed descriptions. Patients may be in their 20 s to their 60s, whereas no elderly patients have been reported. Moreover, 2 of 6 patients (33\%) were hemodialysis patients. The primary infectious site varied among patients, and no patient was affected with IE except for our case. All patients were treated with antimicrobial agents, but whether patients received monotherapy or combination therapy was unclear. Three patients required surgical management, and two patients died during the course of treatment. Based on these findings, SPE caused by

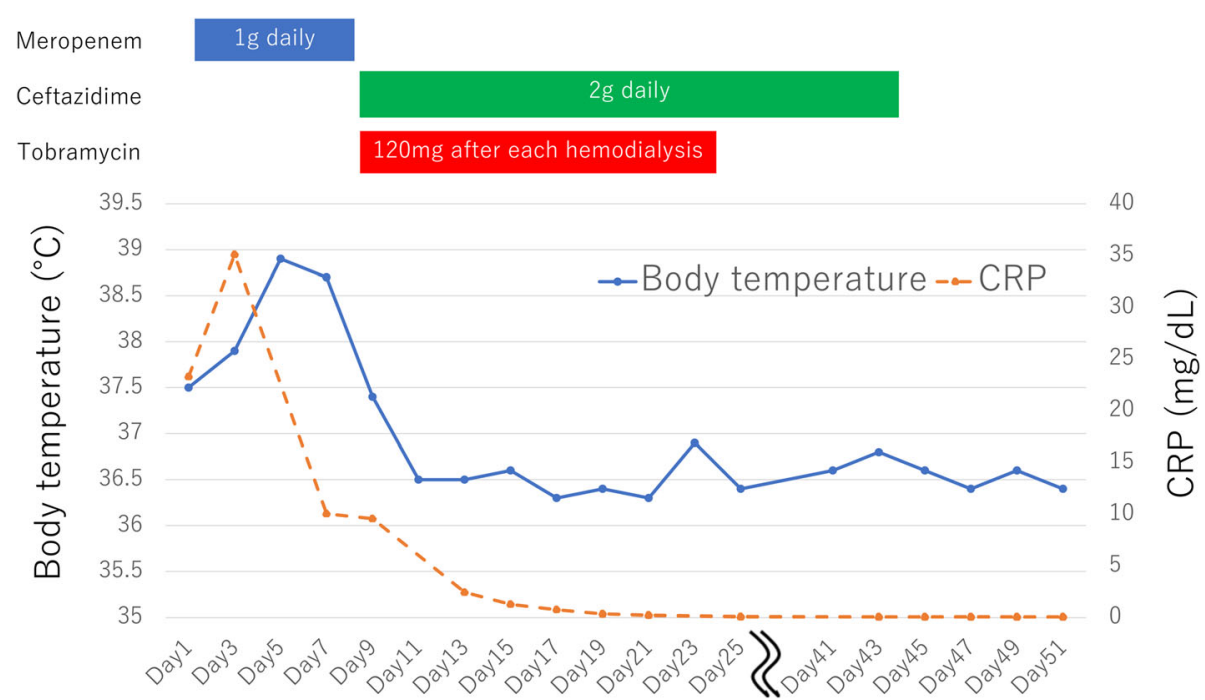

Fig. 2 Clinical course of the patient 
Table 2 Clinical features of 6 reports of septic pulmonary embolism caused by $P$. aeruginosa

\begin{tabular}{|c|c|c|c|c|c|}
\hline & Age/sex & $\begin{array}{l}\text { Maintenance } \\
\text { hemodialysis }\end{array}$ & Primary source of infection & Treatment & Outcome \\
\hline $\begin{array}{l}\text { Present } \\
\text { case }\end{array}$ & 62/male & + & Infective endocarditis & $\mathrm{MEPM} \rightarrow \mathrm{CAZ}+\mathrm{TOB}$ & Survived \\
\hline [7] & Unknown & - & Pneumonia & Tube thoracostomy & Died \\
\hline [8] & 50 s/female & + & Arteriovenous fistula infection & $\begin{array}{l}\text { MEPM } \\
\text { Shunt aneurysmectomy }\end{array}$ & Survived \\
\hline [9] & 50/male & - & Central venous catheter infection & $\mathrm{IPM} \rightarrow \mathrm{CAZ} \rightarrow \mathrm{CPFX}$ & Survived \\
\hline [10] & $\begin{array}{l}\text { 25/ } \\
\text { unknown }\end{array}$ & - & $\begin{array}{l}\text { Necrotizing fasciitis of the upper } \\
\text { limb }\end{array}$ & Antibiotics (details unknown) & Survived \\
\hline [11] & 52/female & - & Arterial thrombi & $\begin{array}{l}\text { Thrombectomy antibiotics (details } \\
\text { unknown) }\end{array}$ & Died \\
\hline
\end{tabular}

MEPM meropenem, CAZ ceftazidime, TOB tobramycin, IPM imipenem, CPFX ciprofloxacin

$P$. aeruginosa could be an uncommon but life-threatening disorder.

The mainstay of SPE treatment is the use of empiric broad-spectrum antibiotics for 4-6 weeks and the approach taken for the primary site of infection $[4,12]$. We, therefore, devised a treatment plan based on IE treatment. For IE treatment, in addition to antibiotics, surgical intervention is indicated in cases of valvular dysfunction that result in heart failure, new heart block, aortic root or annular abscess, penetrating complications, persistent bacteremia, fungemia or infection with some other resistant organism, persistent emboli, enlargement of vegetation despite appropriate antibiotic treatment, or mobile vegetations $>1 \mathrm{~cm}$ for left-sided and $2 \mathrm{~cm}$ for right-sided IE [13]. On the contrary, some reports recommend early valve replacement surgery in cases of $P$. aeruginosa-induced IE [14]. Pseudomonas aeruginosa infections are often difficult to eradicate because this organism gradually develops antibiotic resistance depending on the duration of therapy. Relapses after a seemingly successful treatment are not uncommon [15]. In addition, it is well known that there is a discrepancy between the in vitro and in vivo antibiotic susceptibilities of $P$. aeruginosa, although the mechanism of this phenomenon remains to be clarified [16]. Some cases, including ours, are refractory to antibiotic therapy despite the evidence of in vitro drug susceptibility.

In contrast, some reports recommend using combination antibiotic therapy, typically with antipseudomonal $\beta$-lactams and an aminoglycoside, for $P$. aeruginosa-induced IE to prevent acquisition of drug resistance [17]. In our case, first line monotherapy failed to control the bacteremia; however, after switching to combination therapy, the patient exhibited a good response to the treatment without the need for surgical intervention. According to a study, hemodialysis patients undergoing cardiac surgery had high perioperative and mediumterm mortality because of valve disease, poor left ventricular function, and other underlying conditions [18].
Therefore, combination antibiotic therapy may have a significant benefit in avoiding high-risk surgical interventions in hemodialysis patients.

SPE is a potentially fatal disease, with a reported mortality rate of $10 \%-20 \%[4,6]$. SPE with IE caused by P. aeruginosa is more likely to have poor outcomes because IE due to $P$. aeruginosa has a very high mortality rate of $30 \%-60 \%$ [19-21]. In the analysis of IE caused by nonHACEK (species other than Haemophilus, Actinobacillus actinomycetemcomitans, Cardiobacterium hominis, Eikenella corrodens, or Kingella) gram-negative bacilli, the mortality of IE due to $P$. aeruginosa was high (36\%) despite high rates of cardiac surgery (55\%) [22]. Therefore, IE due to $P$. aeruginosa requires prompt and effective treatment. Our case indicates that combination antibiotic therapy may be a preferable choice for the initial treatment of SPE associated with IE caused by $P$. aeruginosa.

In conclusion, we experienced a rare case of SPE associated with IE caused by $P$. aeruginosa in a hemodialysis patient. The patient was successfully treated with the combination of antipseudomonal $\beta$-lactams and an aminoglycoside and avoided surgical intervention. SPE caused by $P$. aeruginosa is an uncommon but serious disorder, and thus early, appropriate treatment is important. Combination antibiotic therapy with antipseudomonal $\beta$-lactams and an aminoglycoside may be effective in the treatment of SPE associated with IE caused by $P$. aeruginosa, particularly in hemodialysis patients. Further studies are required to examine the effectiveness of this therapy with a greater number of patients.

\section{Abbreviations}

CT: Computed tomography; IE: Infective endocarditis; MEPM: Meropenem; P. aeruginosa: Pseudomonas aeruginosa; SPE: Septic pulmonary embolism; TOB: Tobramycin

\section{Acknowledgements}

We thank Dr. Hiroo Matsuo for his kind support in the treatment of this patient. 


\section{Authors' contributions}

HS designed this study and wrote the initial draft. HS, MT, YT, MT, KM, HS, $\mathrm{SN}, \mathrm{KT}, \mathrm{SI}, \mathrm{MI}$, and $\mathrm{HT}$ participated in the discussion and treatment of the patient. MT reviewed and revised the manuscript. All authors read and approved the manuscript and agree with the submission to this journal.

\section{Funding}

Not applicable.

\section{Availability of data and materials}

Data and materials relevant to this case presentation are all included in this manuscript.

\section{Ethics approval and consent to participate}

This report was written in compliance with the Declaration of Helsinki. For this type of case report, ethics approval is not required.

\section{Consent for publication}

Written informed consent was obtained from the patient for the publication of this case report.

\section{Competing interests}

The authors declare that they have no competing interests.

Received: 25 September 2019 Accepted: 24 February 2020

Published online: 05 March 2020

\section{References}

1. Bach AG, Restrepo CS, Abbas J, Villanueva A, Lorenzo Dus MJ, Schöpf R, et al. Imaging of nonthrombotic pulmonary embolism: biological materials, nonbiological materials, and foreign bodies. Eur J Radiol. 2013;82(3)::120-41.

2. Cook RJ, Ashton RW, Aughenbaugh GL, Ryu JH. Septic pulmonary embolism. Chest. 2005;128(1):162-6.

3. Kuhlman JE, Fishman EK, Teigen C. Pulmonary septic emboli: diagnosis with CT. Radiology. 1990;174(1):211-3.

4. Goswami U, Brenes JA, Punjabi GV, LeClaire MM, Williams DN. Associations and outcomes of septic pulmonary embolism. Open Respir Med J. 2014;8(1):28-33.

5. Jung JS, Lee SM, Kim HJ, Jang S-H, Lee JW. A case of septic pulmonary embolism associated with renal abscess mimicking pulmonary metastases of renal malignancy. Ann Nucl Med. 2014;28(4):381-5.

6. Ye R, Zhao L, Wang C, Wu X, Yan H. Clinical characteristics of septic pulmonary embolism in adults: a systematic review. Respir Med. 2014;108(1):1-8.

7. Chou D-W, Wu S-L, Chung K-M, Han S-C, Cheung BM-H. Septic pulmonary embolism requiring critical care: clinicoradiological spectrum, causative pathogens and outcomes. Clinics (Sao Paulo). 2016;71(10):562-9.

8. Kitajima S, Kaneko S, Wada T. Septic pulmonary embolism caused by internal shunt infection. Ther Apher Dial. 2015;19(5):524-5.

9. Kuwabara M, Itoi K, Ariyasu T, Yanagihara K, Nasu T. Septic pulmonary emboli caused by parenteral nutrition catheter infection. Nihon Kyobu Shikkan Gakkai Zasshi. 1990;28(9):1257-62.

10. Mullick P, Sachdeva HC, Bundela P, Prakash S, Gogia AR. Septic pulmonary embolism following necrotizing fasciitis of the upper limb. J Anaesthesiol Clin Pharmacol. 2013;29(3):416-8.

11. Nishikura T, Ishii T, Ikemura S, Ono M, Kozawa S. Septic pulmonary emboli related to infected arterial thrombi in an extensively burned patient. Nihon Kyukyu Igakukai Zasshi. 2007:18(11):763-8,

12. Lee S-J, Cha S-I, Kim C-H, Park J-Y, Jung T-H, Jeon K-N, et al. Septic pulmonary embolism in Korea: Microbiology, clinicoradiologic features, and treatment outcome. J Infect. 2007;54(3):230-4.

13. Arthur J, Havyarimana J, Norse AB. Emergency department diagnosis of septic pulmonary embolism due to infectious endocarditis using bedside ultrasound. J Emerg Med. 2018;55(3):378-82.

14. Baddour LM, Wilson WR, Bayer AS, Fowler VG, Bolger AF, Levison ME, et al. Infective endocarditis: diagnosis, antimicrobial therapy, and management of complications: a statement for healthcare professionals from the Committee on Rheumatic Fever, Endocarditis, and Kawasaki Disease, Council on Cardiovascular Disease in the Young, and the Councils on Clinical Cardiology, Stroke, and Cardiovascular Surgery and Anesthesia, American
Heart Association: endorsed by the Infectious Diseases Society of America. Circulation. 2005:111(23):e394-434.

15. Osmon S, Ward S, Fraser VJ, Kollef MH. Hospital mortality for patients with bacteremia due to Staphylococcus aureus or Pseudomonas aeruginosa. Chest. 2004;125(2):607-16.

16. Fichtenbaum CJ, Smith MJ. Treatment of endocarditis due to Pseudomonas aeruginosa with imipenem. Clin Infect Dis. 1992;14(1):353-4.

17. Gavin PJ, Suseno MT, Cook FV, Peterson LR, Thomson RB. Left-sided endocarditis caused by Pseudomonas aeruginosa: successful treatment with meropenem and tobramycin. Diagn Microbiol Infect Dis. 2003;47(2):427-30.

18. Leontyev S, Davierwala PM, Gaube L-M, Röhrig KA, Lehmann S, Holzhey DM, et al. Outcomes of dialysis-dependent patients after cardiac operations in a single-center experience of 483 patients. Ann Thorac Surg. 2017;103(4): 1270-6.

19. Komshian SV, Tablan OC, Palutke W, Reyes MP. Characteristics of left-sided endocarditis due to Pseudomonas aeruginosa in the Detroit Medical Center. Rev Infect Dis. 1990;12(4):693-702.

20. Levine DP, Crane LR, Zervos MJ. Bacteremia in narcotic addicts at the Detroit Medical Center. II. Infectious endocarditis: a prospective comparative study. Rev Infect Dis. 8(3):374-96.

21. Wieland M, Lederman MM, Kline-King C, Keys TF, Lerner PI, Bass SN, et al. Left-sided endocarditis due to Pseudomonas aeruginosa. A report of 10 cases and review of the literature. Medicine (Baltimore). 1986;65(3):180-9.

22. Morpeth S, Murdoch D, Cabell CH, Karchmer AW, Pappas P, Levine D, et al. Non-HACEK gram-negative bacillus endocarditis. Ann Intern Med. 2007; 147(12):829-35

\section{Publisher's Note}

Springer Nature remains neutral with regard to jurisdictional claims in published maps and institutional affiliations.

Ready to submit your research? Choose BMC and benefit from:

- fast, convenient online submission

- thorough peer review by experienced researchers in your field

- rapid publication on acceptance

- support for research data, including large and complex data types

- gold Open Access which fosters wider collaboration and increased citations

- maximum visibility for your research: over $100 \mathrm{M}$ website views per year

At $\mathrm{BMC}$, research is always in progress.

Learn more biomedcentral.com/submissions 